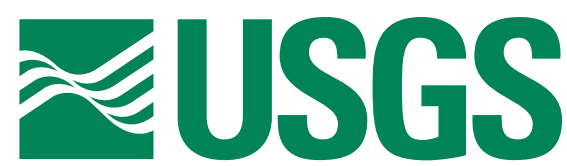

science for a changing world

\title{
Linear Extension Rates of Massive Corals from the Dry Tortugas National Park (DRTO), Florida
}

By Adis Muslic, Jennifer A. Flannery, Christopher D. Reich, Daniel K. Umberger, Joseph M. Smoak, and Richard Z. Poore

Open-File Report 2013-1121

U.S. Department of the Interior

U.S. Geological Survey 


\section{U.S. Department of the Interior \\ SALLY JEWELL, Secretary}

\section{U.S. Geological Survey \\ Suzette M. Kimball, Acting Director}

U.S. Geological Survey, Reston, Virginia: 2013

For more information on the USGS-the Federal source for science about the Earth, its natural and living resources, natural hazards, and the environment-visit http://www.usgs.gov or call 1-888-ASK-USGS

For an overview of USGS information products, including maps, imagery, and publications, visit $h$ ttp://www.usgs.gov/pubprod

To order this and other USGS information products, visit http://store.usgs.gov

Suggested citation:

Muslic, Adis, Flannery, J.A., Reich, C.D., Umberger, D.K., Smoak, J.M., and Poore, R.Z., 2013, Linear extension rates of massive corals from the Dry Tortugas National Park (DRTO), Florida: U.S. Geological Survey Open-File Report 2013-1121, 22 p. (http://pubs.usgs.gov/of/2013/1121/)

Any use of trade, product, or firm names is for descriptive purposes only and does not imply endorsement by the U.S. Government.

Although this report is in the public domain, permission must be secured from the individual copyright owners to reproduce any copyrighted material contained within this report. 


\section{Contents}

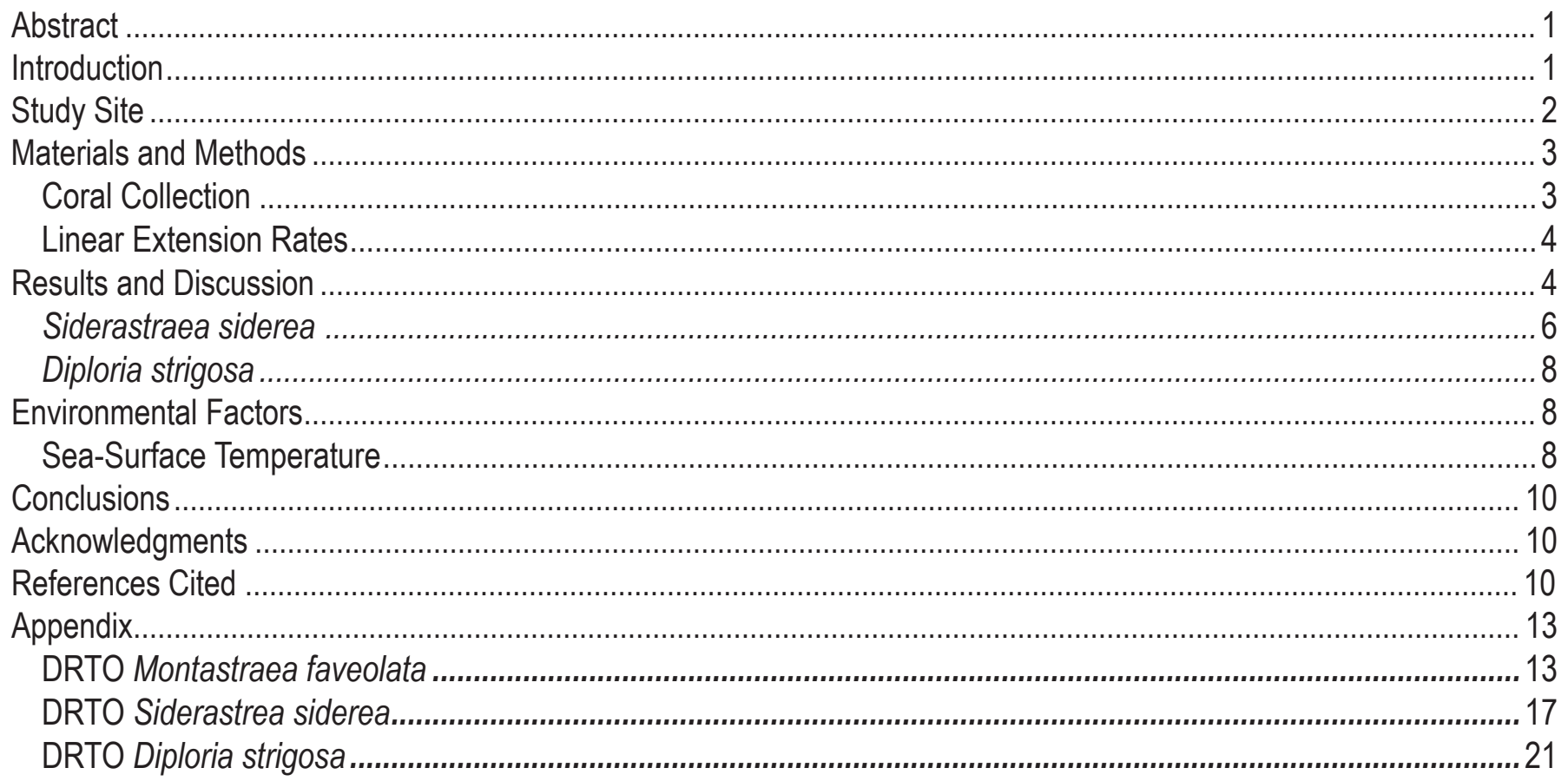

\section{Figures}

1. Map of the Dry Tortugas National Park (DRTO), Florida. The coral core locations and Coastal Marine Automated Networks (C-MAN) stations monitoring SST are denoted on the map by yellow triangles and red circles, respectively. All modern Montastraea faveolata, Siderastrea siderea, and Diploria strigosa coral cores were collected from Pulaski Shoal, and one D. strigosa coral core was collected from Middle Key in August 2008.

2. Average annual linear extension rates (in centimeters) for all DRTO coral cores from 1889 to 2007 with error bars (1б). Y-axis scales were adjusted for each coral to show variability. (A) M. faveolata C2 (B) M. faveolata B3 Slab 2 (C) M. faveolata B3 Slab 4 (D) M. faveolata B3 Composite (E) S. siderea A1 Slab 2 (F) S. siderea A1 Slab 1 (G) S. siderea A1 Slab 2 Composite (H) D. strigosa MK (I) D. strigosa C1

3. (A) Average annual linear extension rates (in centimeters) comparison for M. faveolata B3 Slab 2 (light blue)

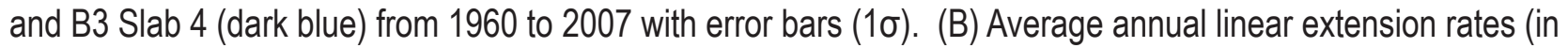
centimeters) comparison for M. faveolata B3 Composite (navy blue) and C2 (teal) from 1938 to 2007 with error bars $(1 \sigma)$.

4. (A) Average annual linear extension rates (in centimeters) comparison for S. siderea A1 Slab 1 (pink) and A1

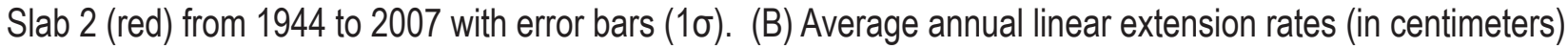
comparison for S. siderea A1 Composite (red) and M. faveolata B3 Composite (navy blue) from 1889 to 2007 with error bars $(1 \sigma)$. Y-axis scales were adjusted for each coral to show variability.

5. (A) Gridded mean annual ICOADS data set centered on $82^{\circ} \mathrm{W}$ and $24^{\circ} \mathrm{N}$ from 1889 to 2007 (orange curve) (B) Average annual linear extension rates (in centimeters) for S. siderea A1 Composite (red curve) with error bars (1s). (C) Mean annual Key West air temperature from 1889 to 2007 (yellow curve).

\section{Tables}

1. Summary of data for cores collected at the Dry Tortugas National Park (DRTO), including collection date, site and reef names, location (latitude and longitude), water depth, and core length. 


\title{
Linear Extension Rates of Massive Corals from the Dry Tortugas National Park (DRTO), Florida
}

By Adis Muslic, Jennifer A. Flannery, Christopher D. Reich, Daniel R. Umberger, Joseph M. Smoak, and Richard Z. Poore

\begin{abstract}
Colonies of three coral species, Montastraea faveolata, Diploria strigosa, and Siderastrea siderea, located in the Dry Tortugas National Park (DRTO), Florida, were sampled and analyzed to evaluate annual linear extension rates. Montastraea faveolata had the highest average linear extension and variability in (DRTO: $\mathrm{C} 2=0.67$ centimeters/year $\left(\mathrm{cm} \mathrm{yr}^{-1}\right) \pm 0.04, \mathrm{~B} 3=0.85 \mathrm{~cm} \mathrm{yr}^{-1} \pm 0.07$ ), followed by $D$. strigosa (DRTO: $\mathrm{C} 1=0.73 \mathrm{~cm} \mathrm{yr}^{-1} \pm 0.04 ; \mathrm{MK}=0.59 \mathrm{~cm} \mathrm{yr}^{-1} \pm 0.06$ ) and $S$. siderea (DRTO: $\mathrm{A} 1=0.41 \mathrm{~cm} \mathrm{yr}^{-1} \pm 0.03$ ). Intercolony comparison of $M$. faveolata from DRTO yielded a significant correlation $(\mathrm{r}=0.34, \mathrm{df}=67, \mathrm{P}=0.005)$ and similar long-term patterns. DRTO $S$. siderea core A1 showed an overall increasing trend $(\mathrm{r}=0.61, \mathrm{df}=119, \mathrm{P}<0.0001)$ in extension rates that correlated significantly with International Comprehensive Ocean/Atmosphere Data Set annual sea-surface temperature $(\mathrm{r}=0.42, \mathrm{df}=115, \mathrm{P}<0.0001)$ and an air temperature record from Key West $(\mathrm{r}=0.37, \mathrm{df}=111$, $\mathrm{P}<0.0001)$. In conclusion, annual linear extension rates are species specific and potentially influenced by long-term variability in sea-surface temperature.
\end{abstract}

\section{Introduction}

Massive reef-building scleractinian corals have the potential for providing detailed information about past environmental conditions and the response of coral reefs to environmental change. The coral skeletons are composed of calcium carbonate in the form of the mineral aragonite. These corals are long-lived (multicentury), and their skeletons exhibit distinct annual density banding. A couplet of high and low density bands represents 1 year of growth. Some species, such as Montastraea faveolata, form their high density bands during the summer months, and lower density bands are deposited during the rest of the year (Shinn, 1966; Swart and others, 2002). The annual banding of the skeleton allows precise chronology, coral linear extension rates, and guidance of subannually resolved sampling for geochemical or isotopic analyses.

Changes in the width of annual growth bands, or annual extension rates, of coral skeletons represent one measure of coral growth that can be related to coral health. Coral extension rates are species specific (Buddemeier and others, 1974; Tomascik, 1990; Logan and others, 1994). Buddemeier and others (1974) measured the extension rates of 47 reef-building corals of 15 different species and found that coral linear extension rates were more influenced by species than any environmental factor. However, studies measuring linear extension rates within individual species indicate that a variety of factors correlate with (and may influence) coral linear extension rates. Correlates of mean annual extension rates include season, rainfall (Buddemeier and others, 1974; Alibert and McCulloch, 1997), the El Niño Southern Oscillation (ENSO) cycle (Alibert and McCulloch, 1997), light levels (Bak, and others, 2009), and location within the reef (Cruz-Pinon and others, 2003). 
A number of studies suggest that temperature may be an important control on linear extension rate variability in corals (Shinn, 1966; Carricart-Ganivet, 2004; De'ath and others, 2009), but the results of other studies are conflicting. Some studies indicate that linear extension rates in corals decrease as a result of an increase in sea-surface temperature (SST) (Carricart-Ganivet, 2004; Cooper and others, 2008; De'ath and others, 2009). For example, specimens of genus Porites from the Great Barrier Reef (GBR) experienced a 16 percent decline in extension rates (Cooper and others, 2008). Extension rates in these Porites specimens decreased 1.02 percent $\mathrm{yr}^{-1}$ from 1988 to 2003 as a result of a rise in SST (Cooper and others, 2008). Carricart-Ganivet (2004) determined that decreasing trends in linear extension rates are correlated with increasing SST by measuring linear extension rates from Montastraea annularis from six locations across the Gulf of Mexico.

Other studies concluded that linear extension rates increased with increasing SST (Shinn, 1966; Dodge and Lang, 1983). Dodge and Lang (1983) found that extension rates in M. annularis from the Gulf of Mexico increased with increasing SST. Additionally, some other studies concluded that SST had no significant correlation with coral extension rates (Gladfelter and others, 1978; Bak and others, 2009; Helmle and others, 2011).

A study was conducted by the U.S. Geological Survey (USGS) to report linear extension rate measurements for several common massive reef building corals in the Dry Tortugas National Park (DRTO), Florida. The study included three species (Siderastraea siderea, Montastraea faveolata, and Diploria Strigosa) of coral collected from the DRTO.

\section{Study Site}

The DRTO (fig. 1) is located 112.9 kilometers $(\mathrm{km})$ west of Key West, Florida (http://www. nps.gov/drto/index.htm), the closest inihabited area to the park. The DRTO forms an elliptical atolllike structure that is $27 \mathrm{~km}$ along the major axis (southwest-northeast) and $12 \mathrm{~km}$ along the minor axis (Davis, 1982). The three major banks- Pulaski Shoal (northeast), Long Key (south), and Loggerhead Key (west) - are separated by 10-20 meter (m) deep channels. The average water depth of the banks is $2-3 \mathrm{~m}$, and the banks are surrounded by $12-23 \mathrm{~m}$ deep lagoons. The Holocene reefs composing the DRTO are situated on the South Florida margin and occupy a transitional zone between the south- and east-facing rimmed margin and the west-facing ramp margin (Mallinson and others, 2003). The reefs are situated on the Key Largo Limestone platform composed mainly of older ( $\sim 125$ thousand years old) massive coral heads (Hickey and others, 2012). 


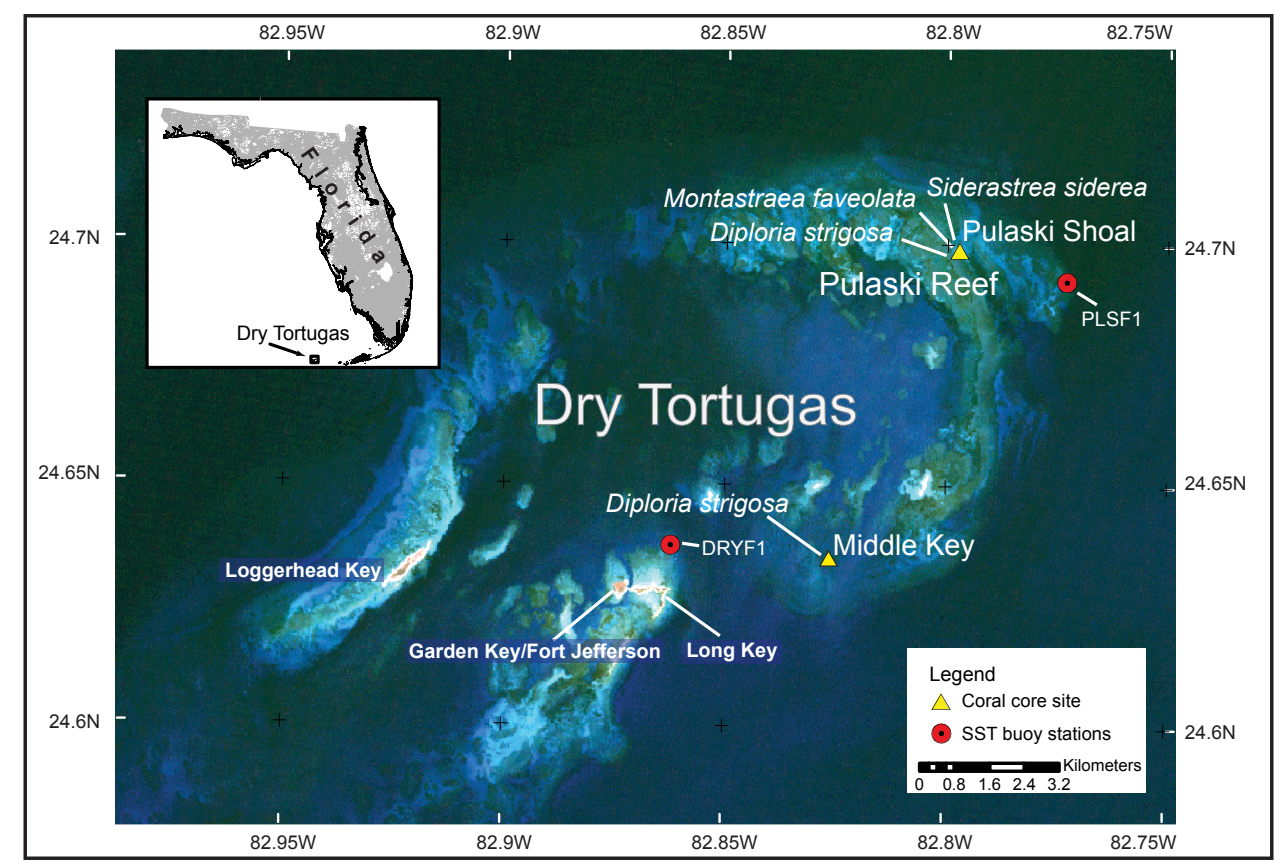

Figure 1. Map of the Dry Tortugas National Park (DRTO), Florida. The coral core locations and Coastal Marine Automated Networks (C-MAN) stations monitoring SST are denoted on the map by yellow triangles and red circles, respectively. All modern Montastraea faveolata, Siderastrea siderea, and Diploria strigosa coral cores were collected from Pulaski Shoal, and one D. strigosa coral core was collected from Middle Key in August 2008.

\section{Materials and Methods}

\section{Coral Collection}

The DRTO coral cores were collected from Pulaski Shoal and Middle Key, Florida, in August 2008. The cores were collected from live coral heads at water depths ranging from 3.4 to $4.3 \mathrm{~m}$ (table 1), using the USGS rotary hydraulic coring system.

Table 1. Summary of data for cores collected at the Dry Tortugas National Park (DRTO), including collection date, site and reef names, location (latitude and longitude), water depth, and core length.

\begin{tabular}{|c|l|l|l|l|l|c|c|}
\hline Core & \multicolumn{1}{|c|}{ Date } & \multicolumn{1}{|c|}{ Location } & \multicolumn{1}{|c|}{ Coral Species } & \multicolumn{1}{c|}{ Latitude (N) } & Longitude (W) & Water Depth (m) & Core Length (cm) \\
\hline B3 & $8 / 7 / 2008$ & Pulaski Shoal & Montastraea faveolata & 24.699 & 82.799 & 3.4 & 142 \\
\hline C2 & $8 / 8 / 2008$ & Pulaski Shoal & Montastraea faveolata & 24.695 & 82.795 & 3.7 & 156 \\
\hline C1 & $8 / 7 / 2008$ & Pulaski Shoal & Diploria strigosa & 24.699 & 82.798 & 3.4 & 3.4 \\
\hline MK & $8 / 6 / 2008$ & Middle Key & Diploria strigosa & 24.645 & 82.832 & 23 \\
\hline A1 & $8 / 6 / 2008$ & Pulaski Shoal & Siderastrea siderea & 24.699 & 82.798 & 4.3 & 113 \\
\hline
\end{tabular}


The equipment used for drilling included a hydraulic-powered submersible drill, a 10-centimeter (cm) diameter by $61-\mathrm{cm}$ long core barrel with a surface set diamond bit and a hydraulic power unit operated from the boat. Corals were drilled along their vertical growth. Following drilling, cores were taken to the USGS Coastal and Marine Science Center in St. Petersburg, Florida, where they were cut into 5 millimeter (mm) thick slabs along their maximum growth axis (Reich and others, 2009; Hickey and others, 2012). The DRTO slabs were x-rayed at Louisiana State University by an AGFA CR 35-X machine at 55 kiloVolts $(\mathrm{kV})$ for 2.5 milliAmp seconds (mAs). The $\mathrm{x}$-ray images were converted into Adobe Photoshop files with 100 pixel $\mathrm{cm}^{-1}$ resolution.

\section{Linear Extension Rates}

Extension rate measurements were made on coral x-ray images using the ruler tool in Adobe Photoshop. Measurements were made along the thecal wall, a part of the skeleton where calcium carbonate is deposited continuously and high and low density bands are distinguished. Linear distance between the tops of successive high density bands was measured. Since the high density bands are formed during the late summer and early fall (Swart and others, 2002), a coral year does not correspond to a calendar year. For consistency, in comparisons to other parameters, it is assumed that each coral year starts on the $1^{\text {st }}$ day of September.

Eight flat coral slabs from five different DRTO cores from three different species (M. faveolata, S. siderea, and D. strigosa) were analyzed from the DRTO (nomenclature for cores and slabs used in this text is found in table 1). Intracolony replication was performed on two slabs of M. faveolata and $S$. siderea, and intercolony comparison was done on two different $M$. faveolata and $D$. strigosa colonies. In an effort to reduce measuring errors, paths with clear, distinguished high and low density bands were chosen over those with less clear banding. At least three linear extension transects for each year were measured from each DRTO coral slab.

Siderastrea siderea deposits calcium carbonate more evenly throughout the year, causing high and low density bands to be less distinctive than the other two species, proving more difficult to designate a starting and ending point of each density band. Montastraea faveolata polyps tend to have meandering paths that grow at an angle, which appear shorter or longer on the x-ray than they actually are, leading to incorrect measurements. To avoid this discrepancy, paths were measured until meandering started, then another path was chosen for measuring.

The coral density bands on the x-rays were counted backward from 2008 down core for DRTO corals, excluding year 2008 because data for this year were incomplete and lacked high density band formation. In cases where multiple slabs were analyzed for the same core, the results were averaged to form a composite record. Statistical calculations were made using Microsoft Office Excel 2010 by applying standard statistical procedures for average and standard deviation. Correlations between coral linear extension rates and environmental parameters (including SST) were made using standard linear regression with 95 percent confidence interval $(\alpha=0.05)$.

\section{Results and Discussion}

Montastraea faveolata had the highest average extension rate and variability of all three species from DRTO. The average linear extension rates of $M$. faveolata cores (fig. 2A-D; $22=0.67 \mathrm{~cm}$ $\mathrm{yr}^{-1} \pm 0.04\left(\mathrm{n}=69\right.$ (number of years)); $\left.\mathrm{B} 3=0.85 \mathrm{~cm} \mathrm{yr}^{-1} \pm 0.07(\mathrm{n}=119)\right)$ were within the range $(0.38$ to $0.98 \mathrm{yr}^{-1}$ ) for this species for studies throughout the Caribbean (Carricart-Ganivet and others, 2000; Helmle and others, 2011). For example, average linear extension rates for $M$. faveolata varied from 
$0.38 \mathrm{~cm} \mathrm{yr}^{-1}$ in Discovery Bay, Jamaica (Dustan, 1975), to $0.87 \mathrm{~cm} \mathrm{yr}^{-1}$ in the Mexican Caribbean Carricart-Ganivet and others, 2000), and $0.91 \mathrm{~cm} \mathrm{yr}^{-1}$ to $0.98 \mathrm{~cm} \mathrm{yr}^{-1}$ in St. Croix, U.S. Virgin Islands (Baker and Weber, 1975; Dodge and Brass, 1984, respectively).

(B)
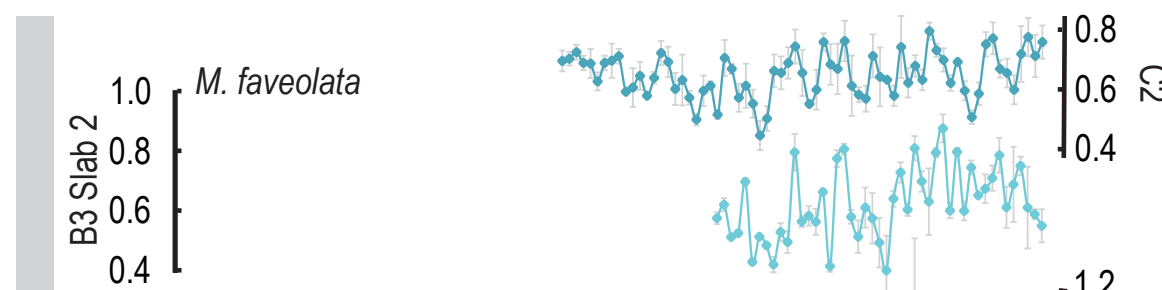

(D)
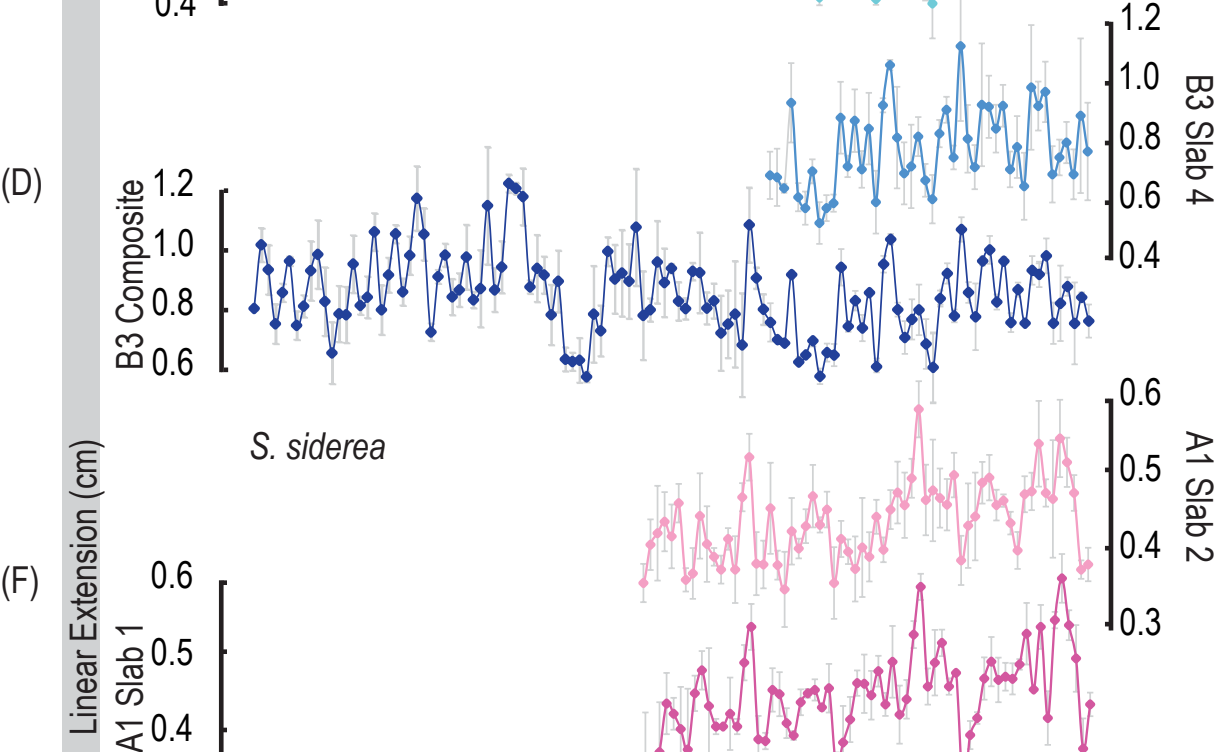

(H)

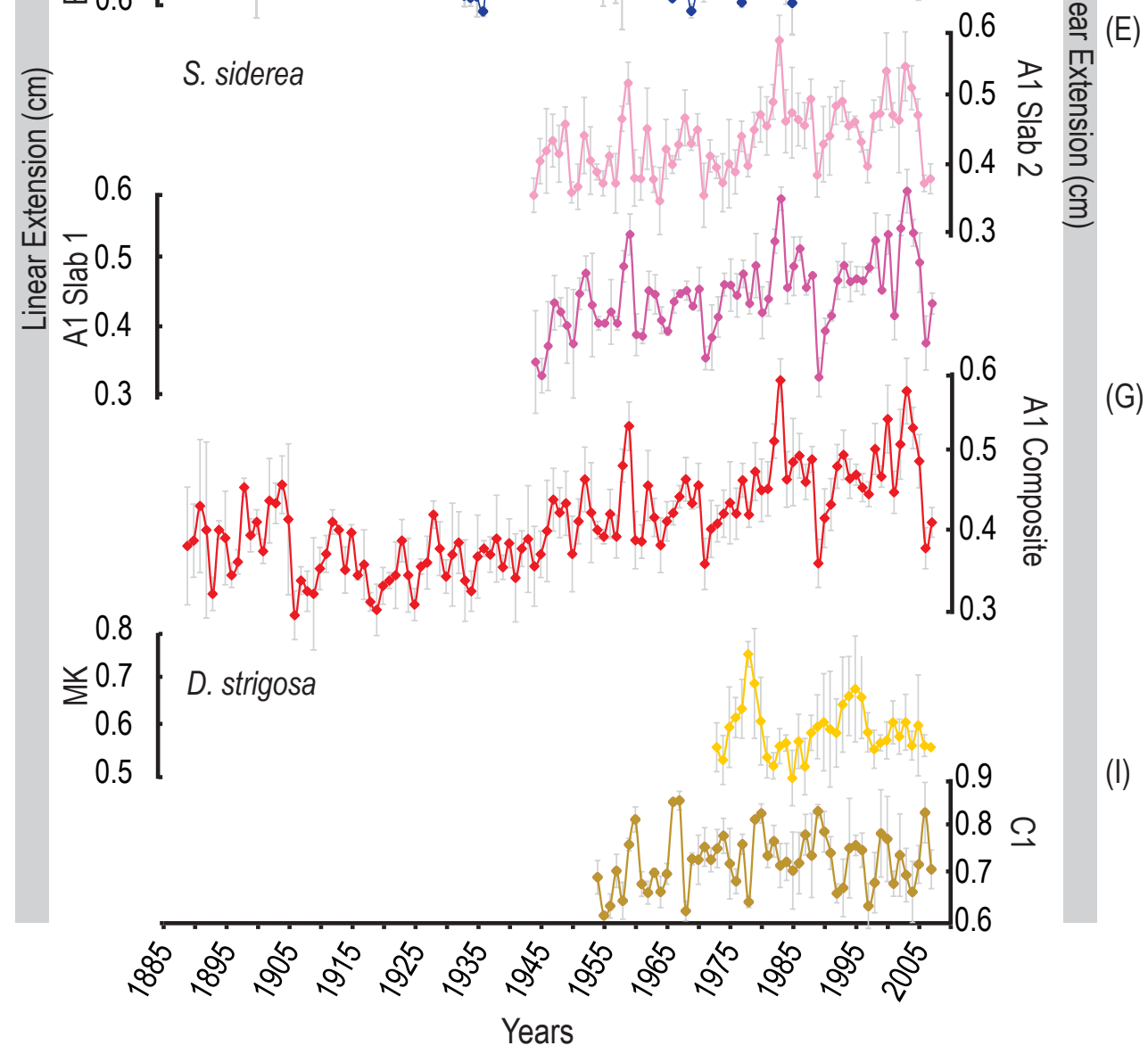

Figure 2. Average annual linear extension rates (in centimeters) for all DRTO coral cores from 1889 to 2007 with error bars $(1 \sigma)$. Y-axis scales were adjusted for each coral to show variability. (A) M. faveolata C2 (B) M. faveolata B3 Slab 2 (C) M. faveolata B3 Slab 4 (D) M. faveolata B3 Composite (E) S. siderea A1 Slab 2 (F) S. siderea A1 Slab $1(\mathrm{G})$ S. siderea A1 Slab 2 Composite (H) D. strigosa MK (I) D. strigosa C1. 
Intracolony correlation between different slabs from the same species (slabs 2 and 4) was high in M. faveolata B3 (fig. 3A, $\mathrm{r}=0.82$, $\mathrm{df}=44, \mathrm{P}<0.0001$ ), most likely resulting from a combination of genetics (because they are from the same colony; (Oliver, 1968)) and picking paths with similar coral polyp orientation.

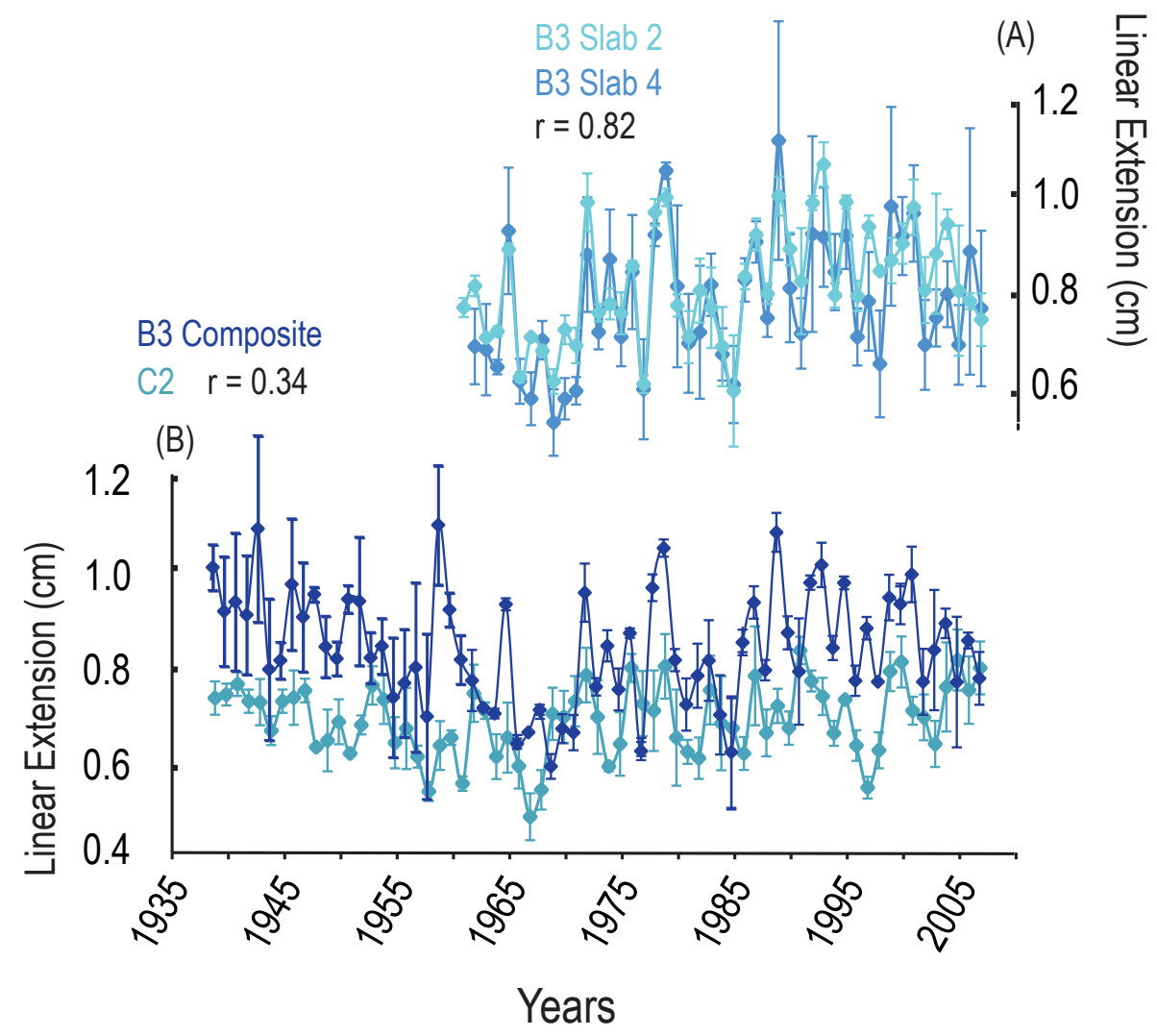

Figure 3. (A) Average annual linear extension rates (in centimeters) comparison for M. faveolata B3 Slab 2 (light

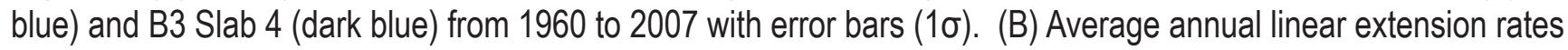
(in centimeters) comparison for M. faveolata B3 Composite (navy blue) and C2 (teal) from 1938 to 2007 with error bars $(1 \sigma)$.

Intracolony $M$. faveolata slabs had a higher correlation than intercolony $M$. faveolata slabs. Montastaea faveolata cores B3 and C2 had a significant positive correlation with each other (fig. 3, $\mathrm{r}=0.34, \mathrm{df}=67, \mathrm{P}=0.0043$ ), although $M$. faveolata core B3 had a 25.4 percent higher average extension rate than $M$. faveolata $\mathrm{C} 2$. Both $M$. faveolata cores B3 and C2 showed a slight negative trend until the late1960s (fig. 3B). It is likely that both M. faveolata colonies experienced similar environmental conditions because they were collected from the same reef patch from similar water depths $(\sim 3.5 \mathrm{~m}$; table 1).

\section{Siderastraea siderea}

Of the three DRTO species, Siderastrea siderea A1 had the lowest extension rates $(0.41 \mathrm{~cm}$ $\mathrm{yr}^{-1} \pm 0.03(\mathrm{n}=119)$, fig. 2D,E), approximately $0.3 \mathrm{~cm} \mathrm{yr}^{-1}$ less than those determined from $S$. siderea specimens from Panama (Guzman and Tudhope, 1998) but similar to S. siderea specimens from Puerto 
Rico (0.35 to $0.43 \mathrm{~cm} \mathrm{yr}^{-1}$; Torres and Morelock, 2002). Like M. faveolata, two intracolony slabs from $S$. siderea A1 were highly correlated with one another (fig. $3 \mathrm{~A}, \mathrm{r}=0.95$, $\mathrm{df}=62, \mathrm{P}<0.0001$ ). Intracolony comparison of $S$. siderea reveals a higher correlation $(\mathrm{r}=0.95)$ than that of . faveolata $(\mathrm{r}=0.82)$.

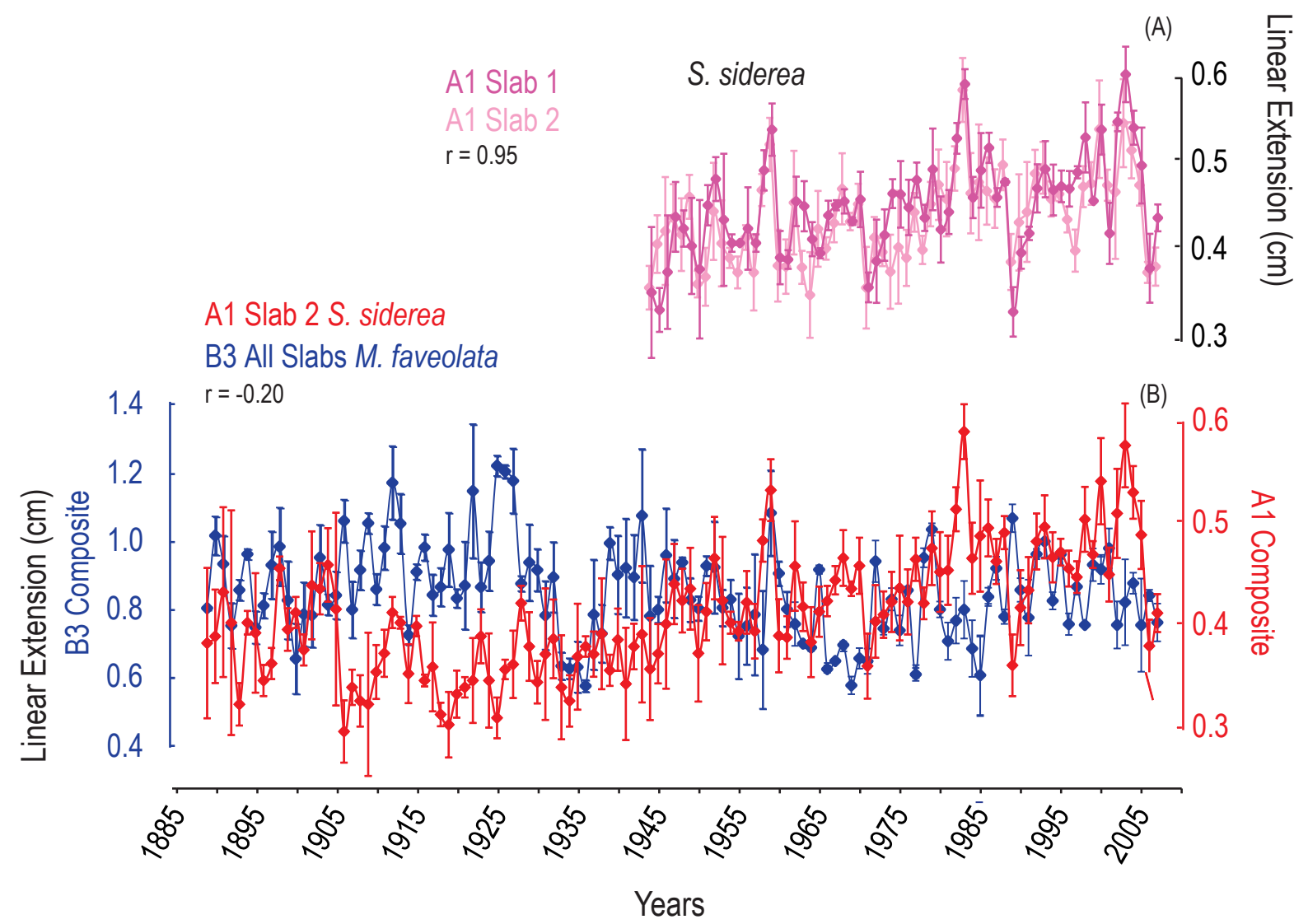

Figure 4. (A) Average annual linear extension rates (in centimeters) comparison for S. siderea A1 Slab 1 (pink) and

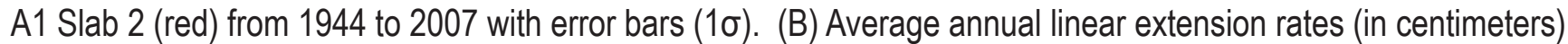
comparison for S. siderea A1 Composite (red) and M. faveolata B3 Composite (navy blue) from 1889 to 2007 with error bars $(1 \sigma)$. Y-axis scales were adjusted for each coral to show variability.

Montastraea faveolata B3 had a significant negative correlation with $S$. siderea A1 (fig. 4B, $\mathrm{r}=-0.20, \mathrm{df}=117, \mathrm{P}=0.0292)$. Siderastrea siderea $\mathrm{A} 1$ had a significant overall positive trend $(\mathrm{r}=0.61, \mathrm{df}=119, \mathrm{P}<0.0001)$ in linear extension rates from 1889 to 2007 , while M. faveolata $\mathrm{B} 3$ had a signifcant negative trend for the same time interval $(\mathrm{r}=-0.22, \mathrm{df}=119, \mathrm{P}=0.0153)$. This suggests that fast-growing $M$. faveolata reacts differently to similar environmental conditions compared to slowgrowing $S$. siderea.

Differences in growth strategies among these species may have contributed to their different responses to environmental challenges. For example, a $S$. siderea from Puerto Rico was found to be tolerant to sedimentation while Montastraea annularis was sensitive to sedimentation (Torres and Morelock, 2002). This implies that coral species respond differently to similar localized environmental conditions. Although the aforementioned study focused on sedimentation, it is conceivable that different coral species may respond differently to other environmental conditions as well, such as SST. Local 
environmental factors may cause extension rates to vary, even in corals that live in close proximity to each other (Heiss, 1996).

\section{Diploria strigosa}

The average extension rates (C2: $\left.0.73 \mathrm{~cm} \mathrm{yr}^{-1} \pm 0.04(\mathrm{n}=54), \mathrm{MK}: 0.59 \mathrm{~cm} \mathrm{yr}^{-1} \pm 0.06(\mathrm{n}=35)\right)$ and variability in Diploria strigosa were lower than those of M. faveolata but higher than that of $S$. siderea (fig. 2). D. strigosa $\mathrm{C} 1$ had extension rates on average 19.6 percent higher than $D$. strigosa $\mathrm{MK}$, and no similar trends or correlations were observed between the two $D$. strigosa cores. X-rays of $D$. strigosa $\mathrm{C} 1$ revealed that the coral had a hyperplasia tumor, typically known to increase coral cell growth leading to abnormally high extension rates (Gateño and others, 2003), as observed in this core. Diploria strigosa MK extension rates were closer to those found elsewhere in the Caribbean Sea and the Gulf of Mexico, suggesting normal growth $\left(0.25 \mathrm{~cm} \mathrm{yr}^{-1}\right.$ to $0.42 \mathrm{~cm} \mathrm{yr}^{-1}$, Logan and others, 1994). Other D. strigosa linear extension rates measured in various locations across the West Atlantic included 0.46-0.59 $\mathrm{cm} \mathrm{yr}^{-1}$ in Panama (Guzman and Cortes, 1989), 0.43-0.46 $\mathrm{cm} \mathrm{yr}^{-1}$ in Aruba (Harriot, 1992), 0.35-1.00 $\mathrm{cm} \mathrm{yr}^{-1}$ in Bahamas (Hubbard and Scaturo, 1985), $0.5 \mathrm{~cm} \mathrm{yr}^{-1}$ in East Flower Banks (Hudson and others, 1994), and $0.33 \mathrm{~cm} \mathrm{yr}^{-1}$ in Bermuda (Johannes and others, 1983). The average extension rate of $0.59 \mathrm{~cm}$ $\mathrm{yr}^{-1}$ in D. strigosa $\mathrm{MK}$ is above regional average but still within the range for the species collected near the Gulf of Mexico.

\section{Environmental Factors}

\section{Sea-Surface Temperature}

Several studies proposed that SST is a leading cause of extension rate variability in corals (Shinn, 1966; Carricart-Ganivet, 2004; De'ath and others, 2009). Three temperature data sets were available in proximity to the coral coring locations: local buoy SST (DRYF1 and PLSF1), Key West air temperature, and the International Comprehensive Ocean-Atmosphere Data Set (ICOADS) SST. Local buoy data sets were collected from Coastal Marine Automated Network (C-MAN) stations PLSF1 (fig. $1 ; 24.69^{\circ} \mathrm{N}, 82.77^{\circ} \mathrm{W}$ ) and C-MAN DRYF1 (fig. $1 ; 24.64^{\circ} \mathrm{N}, 82.86^{\circ} \mathrm{W}$ ). Both stations are located within the boundaries of DRTO (PLSF1 was located at Pulaski Shoal near the locations of the corals). All buoy values were obtained hourly and were computed into average monthly and mean annual SST values. Five complete years of data were available for annual comparisons, making this record the shortest of all three records available. The local buoys likely produced the most comparable SST records, but the records do not cover the necessary time interval. ICOADS SST data contain observations by ships and buoys and are considered by the National Oceanic and Atmospheric Administration (NOAA) to be one of the most complete and heterogeneous collections of SST (http://icoads.noaa.gov/). ICOADS contains the SST for the past 300 years and is arranged in $2^{\circ}$ latitude by $2^{\circ}$ longitude boxes prior to 1959 and $1^{\circ}$ by $1^{\circ}$ since 1960 . The grids used in this study were centered on $82^{\circ} \mathrm{W}$ and $24^{\circ} \mathrm{N}$. Gridded SST data sets such as ICOADS are widely used in coral studies (Payet and Agricole, 2006; Vargas-Angel and others, 2006; Guzman and others, 2008). Lastly, Key West air temperature was recorded daily and sensors were maintained by the National Weather Service (Menne and others, 2011). Air temperature was measured $1.22 \mathrm{~m}$ above sea level at the Key West International Airport (station 084570) from 1895 to 2007. The mean annual Key West air temperature record was compared to the linear extension rates to potentially compensate for the increased ICOADS grid size prior to 1960. 
Mean annual ICOADS SST correlated significantly with $S$. siderea A1 linear extension rates (fig. 5A,B; $\mathrm{r}=0.42$, df $=115, \mathrm{P}<0.0001$ ) but not with the extension rates of the other corals. The mean annual Key West air temperature data also correlated significantly with the A1 linear extension rates (fig. 5B,C; $\mathrm{r}=0.37$, df $=111, \mathrm{P}<0.0001$ ). Slow-growing $S$. siderea produces short yet steady extension rates. The extension rates of the fast-growing $M$. faveolata and D. strigosa had no significant correlation with annual SST. The DRTO results agree with Helmle and others (2011) who found no correlation between $M$. faveolata extension rates and SST from Florida Keys. In agreement with other studies, the linear extension rates were species specific (fig. 2; Buddemeier and others, 1974; Tomascik, 1990; Logan and others, 1994).

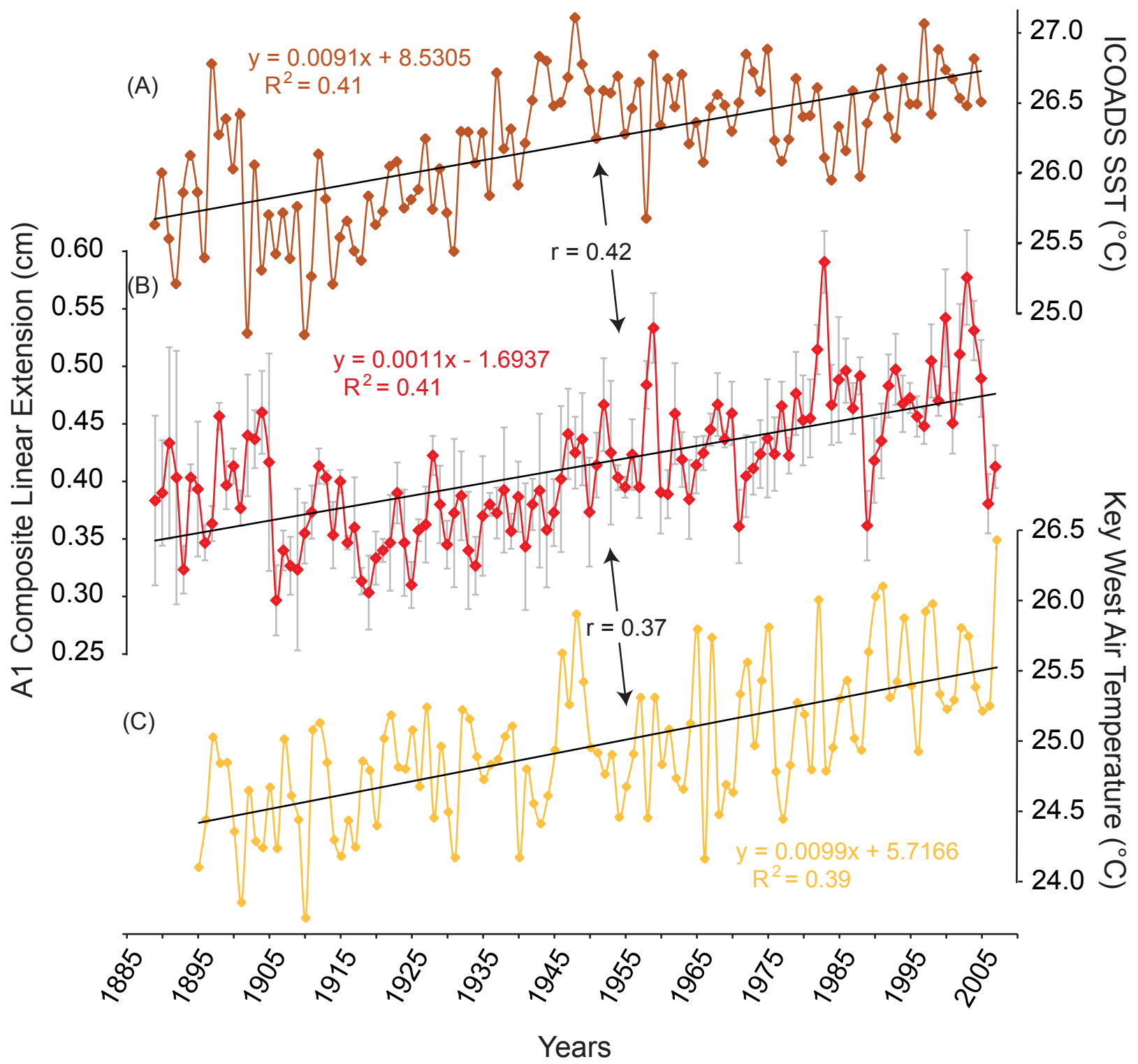

Figure 5. (A) Gridded mean annual ICOADS data set centered on $82^{\circ} \mathrm{W}$ and $24^{\circ} \mathrm{N}$ from 1889 to 2007 (orange curve). (B) Average annual linear extension rates (in centimeters) for S. siderea A1 Composite (red curve) with error bars (1s). (C) Mean annual Key West air temperature from 1889 to 2007 (yellow curve). 


\section{Conclusions}

The current study documents linear extension rates for three massive coral species (Montastraea faveolata, Siderastrea siderea, and Diploria strigosa). It can be concluded that extension rates in the Dry Tortugas National Park are species specific as well as colony specific. Montastraea faveolata had the highest linear extension rates (fastest growth) of all three species in DRTO, and $S$. siderea had the lowest (slowest growth). Intracolony comparisons of both $M$. faveolata and $S$. siderea demonstrate that environmental factors influence each polyp within the colony in a similar way. Intercolony comparisons in $M$. faveolata from DRTO had a significant positive correlation.

Siderastrea siderea and $M$. faveolata produced long linear extension rate records. DRTO $S$. siderea A1 had an overall positive trend that correlated significantly with ICOADS SST (centered on $24^{\circ} \mathrm{N}$ and $82^{\circ} \mathrm{W}$ ) and an air temperature record from Key West, Fla. Both species merit the attention of future studies in the field of climatology for subtropical and tropical oceans.

\section{Acknowledgments}

The authors thank Don Hickey, B.J. Reynolds, Jordan Sanford, David Zawada, Ilsa Kuffner, and Christopher Smith of the USGS. The authors also thank the M/V Fort Jefferson crew, Dry Tortugas National Park personnel, and Kristine DeLong of LSU for discussions that improved the manuscript. We thank CMG for funding. We thank Bayfront Medical Plaza Radiology Department for X-radiograph assistance.

\section{References Cited}

Alibert, C., and McCulloch, M.T., 1997, Strontium/calcium ratios in modern Porites corals from the Great Barrier Reef as a proxy for sea surface temperature: Calibration of the thermometer and monitoring of ENSO: Paleoceanography, v. 12, no. 3, p. 345-363.

Bak, R.P.M., Nieuwland, G., and Meesters, E.H., 2009, Coral growth rates revisited after 31 years: What is causing lower extension rates in Acropora palmata? Bulletin of Marine Science, v. 84, no. 3, p. 287-294.

Baker, P.A., and Weber, J.N., 1975, Coral growth rates: Variation with depth: Earth and Planetary Science Letters, v. 27, p. 57-61.

Buddemeier, R., Maragos, J., and Knutson, D., 1974, Radiographic studies of reef coral exoskeletons: Rates and patterns of coral growth: Journal of Experimental Marine Biology and Ecology, v. 14, no. 2 , p. 179-199.

Carricart-Ganivet, J., 2004, Sea surface temperature and the growth of the West Atlantic Reefbuilding coral Montastraea annularis: Journal of Experimental Marine Biology and Ecology, v. 302, no. 2, p. 249-260.

Carricart-Ganivet, J.P., Beltran-Torres, A.U., Merino, M., and Ruiz-Zarate, M.A., 2000, Skeletal extension, density, and calcification rate of the reef building coral Montastraea annularis (Ellis and Solander) in the Mexican Caribbean: Bulletin of Marine Science, v. 66, no. 1, p. 215-224.

Cooper, T.F., 2008, Declining coral calcification in massive Porites in two nearshore regions of the northern Great Barrier Reef: Global Change Biology, v. 14, p. 529-538. 
Cruz-Pinon, G., Carricart-Ganivet, J.P., and Espinoza-Avalos, J., 2003, Monthly skeletal extension rates of the hermatypic corals Montastraea annularis and Montastraea faveolata: Biological and Environmental Controls: Marine Biology, v. 143, no. 3, p. 491-500.

Davis, G.E., 1982, A century of natural change in coral distribution at the Dry Tortugas: A comparison of reef maps from 1881 and 1976: Bulletin of Marine Science, v. 32, no. 2, p. 608-623.

De'ath, G., Lough, J.M., and Fabricius, K.E., 2009, Declining coral calcification on the Great Barrier Reef: Science, v. 323, no. 5910, p. 116-119.

Dodge, R.E., and Brass, G.W., 1984, Skeletal extension, density and calcification of the reef coral, Montastraea annularis: St. Croix, U.S. Virgin Islands: Bulletin of Marine Science, v. 34, no. 2, p. 288-307.

Dodge, R.E., and Lang, J.C., 1983, Environmental correlates of hermatypic coral (Montastrea annularis) growth on the East Flower Gardens Bank, Northwest Gulf of Mexico: Limnology and Oceanography, v. 28, no. 2, p. 228-240.

Dustan, P., 1975, Growth and form in the reef-building coral Montastrea annularis: Marine Biology, v. 33, no. 2, p. 101-107.

Gateño, D., León, A., Barki, Y., Cortés, J., and Rinkevich, B., 2003, Skeletal tumor formations in the massive coral Pavona clavus: Marine Ecology Progress Series, v. 258, p. 97-108.

Gladfelter, E.G., Monahan, R.K., and Gladfelter, W.B., 1978, Growth rates of five reef-building corals in the northeastern Caribbean: Bulletin of Marine Science, v. 28, no. 4, p. 728-734.

Guzman, H.M., Cipriani, R., and Jackson, J.B.C., 2008, Historical decline in coral reef growth after the Panama Canal: AMBIO: A Journal of the Human Environment, v. 37, no. 5, p. 342-346.

Guzman, H.M., and Cortes, J., 1989, Growth rates of eight species of scleractinian corals in the eastern Pacific (Costa Rica): Bulletin of Marine Science, v. 44, p. 1186-1194.

Guzman, H.M., and Tudhope, A.W., 1998, Seasonal variation in skeletal extension rate and stable isotopic $\left({ }^{13} \mathrm{C} /{ }^{12} \mathrm{C}\right.$ and $\left.{ }^{18} \mathrm{O} /{ }^{16} \mathrm{O}\right)$ composition in response to several environmental variables in the Caribbean reef coral Siderastrea sidereal: Marine Ecology Progress Series, v. 166, p. 109-118.

Harriott, V.J., 1992, Recruitment patterns of scleractinian corals in an isolated sub-tropical reef system: Coral Reefs, v. 11, p. 215-219.

Heiss, G.A., 1996, Annual band width variation in Porites sp. from Aqaba, Gulf of Aqaba, Red Sea: Bulletin of Marine Science, v. 59, no. 2, p. 393-403.

Helmle, K.P., Dodge, R.E., Swart, P.K., Gledhill, D.K., and Eakin, C.M., 2011, Growth rates of Florida corals from 1937 to 1996 and their response to climate change: Nature Communications, v. 2, no. 215, p. 1-6.

Hickey, T.D., Reich, C.D., Delong, K.L., Poore, R.Z., and Brock, J.C., 2012, Holocene core logs and site methods for modern reef and head-coral cores: Dry Tortugas National Park, Florida: U.S. Geological Survey Open-File Report 2012-1095, 34 p. 
Hubbard, D.K., and Scaturo, D., 1985, Growth rates of seven species of scleractinian corals from Cane Bay and Salt River, St. Croix, U.S.V.I.: Bulletin of Marine Science, v. 36, p. 325-38.

Hudson, J., Hanson, K.J., Halley, R.B., and Kindinger, J.L., 1994, Environmental implications of growth rate changes in Montastrea annularis: Biscayne National Park, Florida: Bulletin of Marine Science, v. 54, p. 647-669.

Johannes, R.E., Weibe, W.J., Crossland, C.J., Rimmer, D.W., and Smith, S.V., 1983, Latitudinal limits of coral reef growth: Marine Ecology Progress Series, v. 11, p. 105-111.

Logan, A., Yang, L., and Tomascik, T., 1994, Linear skeletal extension rates in two species of Diploria from high-latitude reefs in Bermuda: Coral Reefs, v. 13, no. 4, p. 225-230.

Mallinson, D., Hine, A., Hallock, P., Locker, S., Shinn, E., Naar, D., Donahue, B., and Weaver, D., 2003, Development of small carbonate banks on the South Florida platform margin: Response to sea level and climate change: Marine Geology, v. 199, no. 1-2, p. 45-63.

Menne, M.J., Williams, C.N., Jr., and Vose, R.S., 2011, United States historical climatology network, Carbon Dioxide Information Analysis Center, Oak Ridge National Laboratory, Department of Energy, Oak Ridge, Tennessee, accessed April 29, 2009, at http://cdiac.ornl.gov/epubs/ndp/ushcn/access.html.

Oliver, W.A., Jr., 1968, Some aspects of colony development in corals: Journal of Paleontology, v. 2, no. 5 , p. 16-34.

Payet, R., and Agricole, W., 2006, Climate change in the Seychelles: Implications for water and coral reefs: AMBIO: A Journal of the Human Environment, v. 35, no. 4, p. 182-189.

Reich, C.D., Hickey, T.D., DeLong, K.L., Poore, R.Z., and Brock, J.C., 2009, Holocene core logs and site statistics for modern patch-reef cores-Biscayne National Park, Florida: U.S. Geological Survey Open-File Report 2009-1246, 26 p.

Shinn, E.A., 1966, Coral growth-rate, An environmental indicator: Journal of Paleontology, v. 40, no. 2, p. 233-240.

Swart, P.K., Elderfield, H., and Greaves, M.J., 2002, A high-resolution calibration of Sr/Ca thermometry using the Caribbean coral Montastraea annularis: Geochemistry Geophysics Geosystems, v. 3, no. 8402, doi:10.1029/2002GC000306.

Tomascik, T., 1990, Growth rates of two morphotypes of Montastrea annularis along a eutrophication gradient, Barbados, W.I.: Marine Pollution Bulletin, v. 21, no. 8, p. 376-381.

Torres, J.L., and Morelock, J., 2002, Effect of terrigenous sediment influx on coral cover and linear extension rates of three Caribbean massive coral species: Caribbean Journal of Science, v. 38, no. 3-4, p. 222-229.

Vargas-Ángel, B., Colley, S.B., Hoke, S.M., and Thomas, J.D., 2006, The reproductive seasonality and gametogenic cycle of Acropora cervicornis off Broward County, Florida, U.S.A.: Coral Reefs, v. 25, no. 1, p. 110-122. 


\section{Appendix}

DRTO Montastraea faveolata

\begin{tabular}{|c|c|c|c|c|c|c|c|c|c|c|c|c|}
\hline Year & B3 Composite & $\begin{array}{c}\text { B3 Composite } \\
\text { Error (1б) } \\
\end{array}$ & $\begin{array}{c}\text { B3 Composite } \\
\text { n n } \\
\end{array}$ & B3 Slab 2 & $\begin{array}{c}\text { B3 Slab } 2 \\
\text { Error (1б) }\end{array}$ & $\begin{array}{c}\text { B3Slab } \\
2 \mathrm{n}\end{array}$ & B3 Slab 4 & $\begin{array}{c}\text { B3 Slab } 4 \\
\text { Error }(1 \sigma)\end{array}$ & $\begin{array}{c}\text { B3Slab } \\
4 \mathrm{n}\end{array}$ & $\mathrm{C} 2$ & $\begin{array}{c}\text { C2 Error } \\
(1 \sigma)\end{array}$ & C2n \\
\hline 2007 & 0.763 & 0.110 & 6 & 0.757 & 0.056 & 3 & 0.77 & 0.164 & 3 & 0.78 & 0.056 & 3 \\
\hline 2006 & 0.843 & 0.138 & 6 & 0.796 & 0.017 & 3 & 0.89 & 0.259 & 3 & 0.733 & 0.071 & 3 \\
\hline 2005 & 0.756 & 0.111 & 6 & 0.818 & 0.137 & 3 & 0.693 & 0.084 & 3 & 0.797 & 0.064 & 3 \\
\hline 2004 & 0.879 & 0.050 & 6 & 0.958 & 0.031 & 3 & 0.8 & 0.069 & 3 & 0.74 & 0.094 & 4 \\
\hline 2003 & 0.823 & 0.093 & 6 & 0.896 & 0.126 & 3 & 0.75 & 0.06 & 3 & 0.62 & 0.049 & 5 \\
\hline 2002 & 0.756 & 0.082 & 6 & 0.819 & 0.069 & 3 & 0.693 & 0.095 & 3 & 0.676 & 0.048 & 5 \\
\hline 2001 & 0.982 & 0.080 & 6 & 0.993 & 0.058 & 3 & 0.97 & 0.102 & 3 & 0.69 & 0.029 & 4 \\
\hline 2000 & 0.920 & 0.062 & 7 & 0.917 & 0.043 & 3 & 0.923 & 0.082 & 4 & 0.793 & 0.054 & 4 \\
\hline 1999 & 0.933 & 0.129 & 7 & 0.881 & 0.048 & 3 & 0.985 & 0.209 & 4 & 0.773 & 0.041 & 4 \\
\hline 1998 & 0.756 & 0.057 & 6 & 0.859 & 0.002 & 3 & 0.653 & 0.112 & 3 & 0.607 & 0.038 & 3 \\
\hline 1997 & 0.869 & 0.064 & 7 & 0.952 & 0.024 & 3 & 0.785 & 0.104 & 4 & 0.528 & 0.023 & 5 \\
\hline 1996 & 0.758 & 0.046 & 6 & 0.807 & 0.032 & 3 & 0.71 & 0.06 & 3 & 0.617 & 0.032 & 3 \\
\hline 1995 & 0.964 & 0.042 & 6 & 1.004 & 0.014 & 3 & 0.923 & 0.070 & 3 & 0.713 & 0.006 & 3 \\
\hline 1994 & 0.827 & 0.053 & 6 & 0.808 & 0.026 & 3 & 0.847 & 0.080 & 3 & 0.643 & 0.026 & 4 \\
\hline 1993 & 1.002 & 0.076 & 6 & 1.083 & 0.047 & 3 & 0.92 & 0.104 & 3 & 0.72 & 0.039 & 4 \\
\hline 1992 & 0.964 & 0.111 & 6 & 1.002 & 0.015 & 3 & 0.927 & 0.206 & 3 & 0.753 & 0.022 & 4 \\
\hline 1991 & 0.778 & 0.093 & 7 & 0.838 & 0.112 & 3 & 0.718 & 0.074 & 4 & 0.817 & 0.029 & 3 \\
\hline 1990 & 0.859 & 0.074 & 7 & 0.906 & 0.035 & 3 & 0.813 & 0.114 & 4 & 0.653 & 0.035 & 3 \\
\hline 1989 & 1.07 & 0.146 & 6 & 1.017 & 0.041 & 3 & 1.123 & 0.251 & 3 & 0.7 & 0.036 & 3 \\
\hline 1988 & 0.781 & 0.031 & 6 & 0.811 & 0.021 & 3 & 0.75 & 0.04 & 3 & 0.643 & 0.049 & 3 \\
\hline 1987 & 0.923 & 0.039 & 6 & 0.936 & 0.034 & 3 & 0.91 & 0.044 & 3 & 0.763 & 0.104 & 3 \\
\hline 1986 & 0.839 & 0.036 & 7 & 0.848 & 0.027 & 4 & 0.83 & 0.046 & 3 & 0.6 & 0.035 & 3 \\
\hline 1985 & 0.608 & 0.099 & 8 & 0.607 & 0.117 & 4 & 0.61 & 0.081 & 4 & 0.653 & 0.006 & 3 \\
\hline 1984 & 0.687 & 0.069 & 7 & 0.7 & 0.083 & 4 & 0.673 & 0.055 & 3 & 0.663 & 0.099 & 3 \\
\hline 1983 & 0.801 & 0.075 & 7 & 0.782 & 0.085 & 4 & 0.82 & 0.066 & 3 & 0.733 & 0.072 & 3 \\
\hline 1982 & 0.769 & 0.104 & 6 & 0.818 & 0.067 & 3 & 0.72 & 0.14 & 3 & 0.59 & 0.044 & 3 \\
\hline 1981 & 0.708 & 0.080 & 6 & 0.72 & 0.055 & 3 & 0.697 & 0.104 & 3 & 0.603 & 0.025 & 3 \\
\hline 1980 & 0.802 & 0.097 & 6 & 0.787 & 0.023 & 3 & 0.817 & 0.170 & 3 & 0.633 & 0.101 & 3 \\
\hline 1979 & 1.037 & 0.018 & 8 & 1.014 & 0.018 & 5 & 1.06 & 0.017 & 3 & 0.783 & 0.068 & 3 \\
\hline
\end{tabular}


DRTO Montastraea faveolata (continued)

\begin{tabular}{|c|c|c|c|c|c|c|c|c|c|c|c|c|}
\hline 1978 & 0.954 & 0.026 & 8 & 0.983 & 0.028 & 4 & 0.925 & 0.024 & 4 & 0.69 & 0.085 & 4 \\
\hline 1977 & 0.611 & 0.062 & 6 & 0.621 & 0.019 & 3 & 0.6 & 0.105 & 3 & 0.705 & 0.069 & 4 \\
\hline 1976 & 0.858 & 0.065 & 6 & 0.87 & 0.01 & 3 & 0.847 & 0.120 & 3 & 0.78 & 0.029 & 4 \\
\hline 1975 & 0.74 & 0.053 & 7 & 0.77 & 0.044 & 3 & 0.71 & 0.062 & 4 & 0.62 & 0.067 & 4 \\
\hline 1974 & 0.832 & 0.069 & 6 & 0.79 & 0.033 & 3 & 0.873 & 0.105 & 3 & 0.573 & 0.010 & 4 \\
\hline 1973 & 0.746 & 0.027 & 6 & 0.771 & 0.018 & 3 & 0.72 & 0.036 & 3 & 0.677 & 0.078 & 3 \\
\hline 1972 & 0.943 & 0.091 & 6 & 1.003 & 0.061 & 3 & 0.883 & 0.121 & 3 & 0.765 & 0.057 & 4 \\
\hline 1971 & 0.649 & 0.033 & 6 & 0.702 & 0.037 & 3 & 0.597 & 0.029 & 3 & 0.71 & 0.053 & 3 \\
\hline 1970 & 0.658 & 0.037 & 6 & 0.736 & 0.030 & 3 & 0.58 & 0.044 & 3 & 0.677 & 0.055 & 3 \\
\hline 1969 & 0.578 & 0.048 & 6 & 0.627 & 0.026 & 3 & 0.53 & 0.07 & 3 & 0.683 & 0.055 & 3 \\
\hline 1968 & 0.697 & 0.026 & 6 & 0.691 & 0.011 & 3 & 0.703 & 0.040 & 3 & 0.523 & 0.042 & 3 \\
\hline 1967 & 0.65 & 0.030 & 6 & 0.72 & 0.003 & 3 & 0.58 & 0.056 & 3 & 0.467 & 0.049 & 3 \\
\hline 1966 & 0.626 & 0.029 & 6 & 0.636 & 0.011 & 3 & 0.617 & 0.047 & 3 & 0.573 & 0.047 & 3 \\
\hline 1965 & 0.919 & 0.073 & 6 & 0.904 & 0.013 & 3 & 0.933 & 0.133 & 3 & 0.633 & 0.074 & 3 \\
\hline 1964 & 0.689 & 0.013 & 6 & 0.732 & 0.010 & 3 & 0.647 & 0.015 & 3 & 0.593 & 0.047 & 3 \\
\hline 1963 & 0.701 & 0.051 & 6 & 0.719 & 0.005 & 3 & 0.683 & 0.096 & 3 & 0.69 & 0.017 & 3 \\
\hline 1962 & 0.759 & 0.051 & 6 & 0.828 & 0.022 & 3 & 0.69 & 0.079 & 3 & 0.727 & 0.060 & 3 \\
\hline 1961 & 0.803 & 0.051 & 3 & 0.782 & 0.020 & 3 & & & & 0.537 & 0.015 & 3 \\
\hline 1960 & 0.908 & 0.036 & 3 & & & & & & & 0.633 & 0.015 & 3 \\
\hline 1959 & 1.086 & 0.125 & 3 & & & & & & & 0.617 & 0.051 & 3 \\
\hline 1958 & 0.683 & 0.174 & 3 & & & & & & & 0.52 & 0.02 & 3 \\
\hline 1957 & 0.787 & 0.178 & 3 & & & & & & & 0.593 & 0.023 & 3 \\
\hline 1956 & 0.753 & 0.114 & 3 & & & & & & & 0.653 & 0.085 & 4 \\
\hline 1955 & 0.723 & 0.126 & 3 & & & & & & & 0.623 & 0.054 & 4 \\
\hline 1954 & 0.831 & 0.059 & 3 & & & & & & & 0.713 & 0.051 & 3 \\
\hline 1953 & 0.807 & 0.054 & 3 & & & & & & & 0.743 & 0.040 & 3 \\
\hline 1952 & 0.926 & 0.135 & 3 & & & & & & & 0.66 & 0.02 & 3 \\
\hline 1951 & 0.93 & 0.029 & 3 & & & & & & & 0.6 & 0 & 3 \\
\hline 1950 & 0.805 & 0.036 & 4 & & & & & & & 0.667 & 0.047 & 3 \\
\hline 1949 & 0.83 & 0.064 & 3 & & & & & & & 0.628 & 0.065 & 4 \\
\hline 1948 & 0.94 & 0.015 & 3 & & & & & & & 0.613 & 0.006 & 3 \\
\hline 1947 & 0.892 & 0.115 & 3 & & & & & & & 0.733 & 0.025 & 4 \\
\hline 1946 & 0.961 & 0.138 & 3 & & & & & & & 0.718 & 0.057 & 4 \\
\hline
\end{tabular}


DRTO Montastraea faveolata (continued)

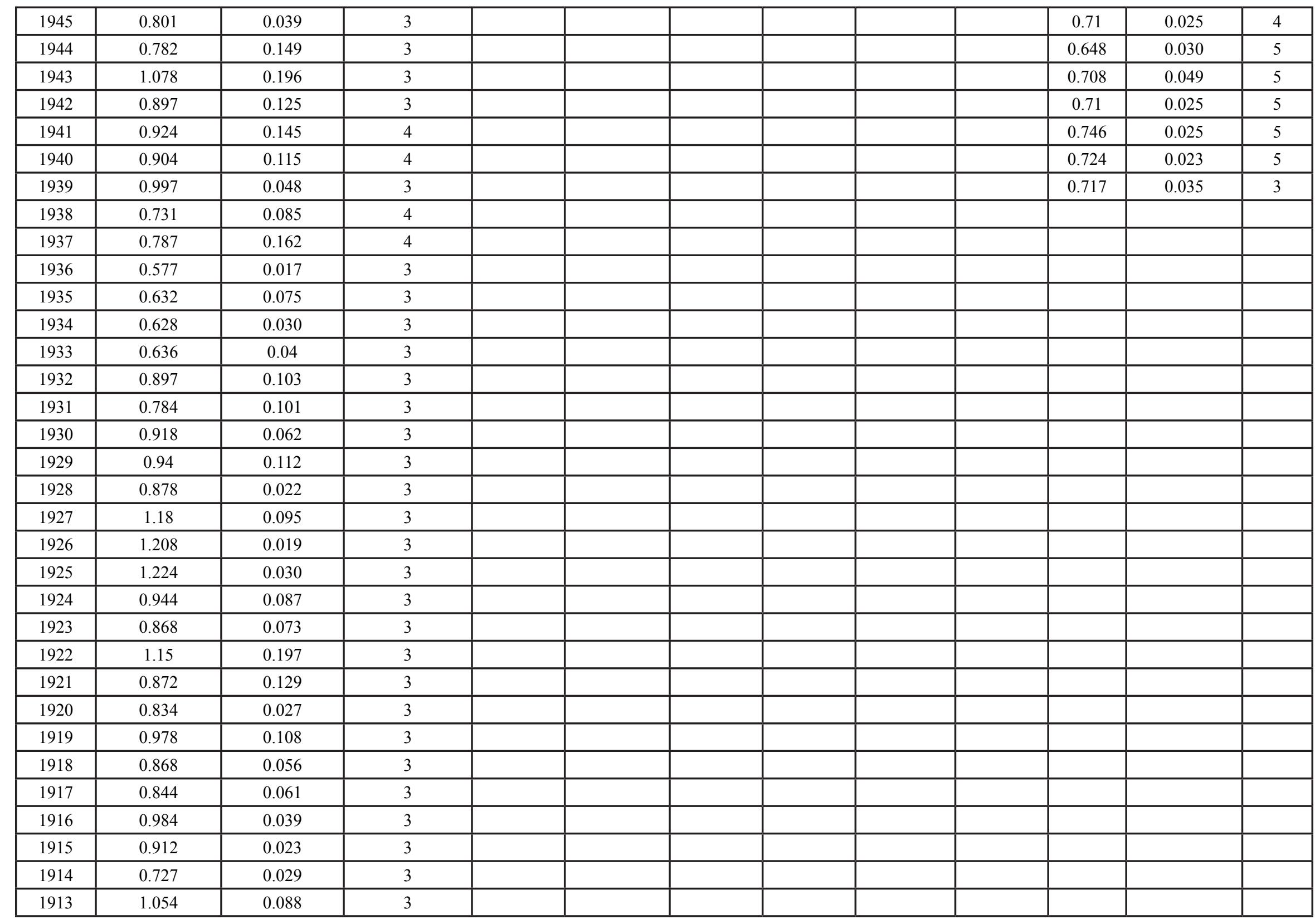


DRTO Montastraea faveolata (continued)

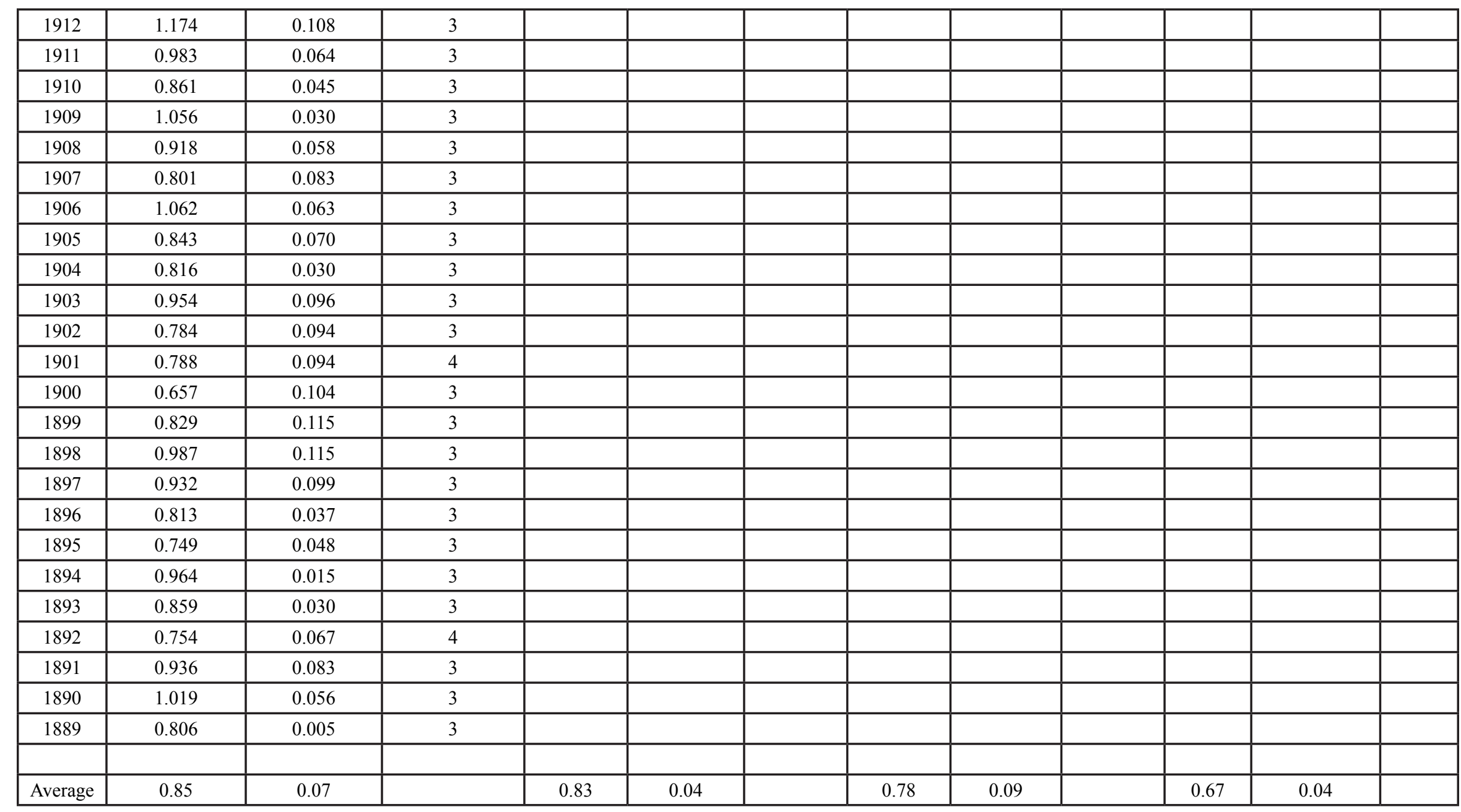


DRTO Siderastrea siderea

\begin{tabular}{|c|c|c|c|c|c|c|c|c|c|}
\hline Year & A1 Composite & $\begin{array}{c}\text { A1 Composite } \\
\text { Error (1б) }\end{array}$ & A1 Composite $n$ & A1 Slab 1 & $\begin{array}{c}\text { A1 Slab } 1 \text { Error } \\
(1 \sigma)\end{array}$ & $\begin{array}{c}\text { A1 Slab } \\
1 \mathrm{n}\end{array}$ & A1 Slab 2 & $\begin{array}{c}\text { A1 Slab } 2 \text { Error } \\
(1 \sigma)\end{array}$ & $\begin{array}{c}\text { A1 Slab } \\
2 \mathrm{n}\end{array}$ \\
\hline 2007 & 0.426 & 0.017 & 6 & 0.439 & 0.015 & 3 & 0.413 & 0.019 & 3 \\
\hline 2006 & 0.381 & 0.033 & 6 & 0.381 & 0.040 & 3 & 0.381 & 0.026 & 3 \\
\hline 2005 & 0.494 & 0.039 & 6 & 0.499 & 0.044 & 3 & 0.489 & 0.033 & 3 \\
\hline 2004 & 0.537 & 0.023 & 6 & 0.542 & 0.020 & 3 & 0.531 & 0.026 & 3 \\
\hline 2003 & 0.590 & 0.037 & 6 & 0.603 & 0.032 & 3 & 0.577 & 0.041 & 3 \\
\hline 2002 & 0.530 & 0.027 & 6 & 0.549 & 0.011 & 3 & 0.511 & 0.044 & 3 \\
\hline 2001 & 0.436 & 0.031 & 7 & 0.421 & 0.035 & 3 & 0.451 & 0.026 & 4 \\
\hline 2000 & 0.541 & 0.036 & 8 & 0.54 & 0.029 & 4 & 0.542 & 0.042 & 4 \\
\hline 1999 & 0.464 & 0.008 & 9 & 0.458 & 0.002 & 4 & 0.470 & 0.013 & 5 \\
\hline 1998 & 0.518 & 0.036 & 7 & 0.531 & 0.040 & 3 & 0.505 & 0.032 & 4 \\
\hline 1997 & 0.470 & 0.011 & 7 & 0.491 & 0.007 & 3 & 0.448 & 0.016 & 4 \\
\hline 1996 & 0.464 & 0.019 & 8 & 0.472 & 0.020 & 3 & 0.456 & 0.018 & 5 \\
\hline 1995 & 0.474 & 0.016 & 8 & 0.475 & 0.018 & 4 & 0.473 & 0.013 & 4 \\
\hline 1994 & 0.469 & 0.027 & 8 & 0.471 & 0.029 & 4 & 0.468 & 0.025 & 4 \\
\hline 1993 & 0.496 & 0.032 & 9 & 0.495 & 0.032 & 5 & 0.497 & 0.031 & 4 \\
\hline 1992 & 0.478 & 0.028 & 9 & 0.473 & 0.028 & 5 & 0.483 & 0.027 & 4 \\
\hline 1991 & 0.428 & 0.020 & 8 & 0.421 & 0.008 & 3 & 0.435 & 0.033 & 5 \\
\hline 1990 & 0.409 & 0.028 & 8 & 0.399 & 0.018 & 3 & 0.418 & 0.037 & 5 \\
\hline 1989 & 0.346 & 0.029 & 8 & 0.331 & 0.028 & 3 & 0.362 & 0.030 & 5 \\
\hline 1988 & 0.486 & 0.010 & 8 & 0.48 & 0.003 & 3 & 0.492 & 0.016 & 5 \\
\hline 1987 & 0.463 & 0.016 & 8 & 0.462 & 0.011 & 3 & 0.463 & 0.022 & 5 \\
\hline 1986 & 0.508 & 0.023 & 9 & 0.519 & 0.017 & 4 & 0.496 & 0.028 & 5 \\
\hline 1985 & 0.491 & 0.049 & 9 & 0.493 & 0.043 & 4 & 0.488 & 0.055 & 5 \\
\hline 1984 & 0.464 & 0.029 & 7 & 0.462 & 0.024 & 3 & 0.467 & 0.035 & 4 \\
\hline 1983 & 0.592 & 0.022 & 7 & 0.592 & 0.017 & 3 & 0.591 & 0.027 & 4 \\
\hline 1982 & 0.522 & 0.020 & 7 & 0.53 & 0.018 & 3 & 0.515 & 0.022 & 4 \\
\hline 1981 & 0.450 & 0.030 & 8 & 0.446 & 0.025 & 3 & 0.455 & 0.034 & 5 \\
\hline 1980 & 0.439 & 0.039 & 9 & 0.426 & 0.038 & 3 & 0.453 & 0.039 & 6 \\
\hline 1979 & 0.485 & 0.042 & 9 & 0.494 & 0.047 & 3 & 0.476 & 0.036 & 6 \\
\hline 1978 & 0.431 & 0.015 & 7 & 0.439 & 0.015 & 3 & 0.422 & 0.016 & 4 \\
\hline 1977 & 0.474 & 0.021 & 6 & 0.482 & 0.020 & 3 & 0.466 & 0.021 & 3 \\
\hline
\end{tabular}


DRTO Siderastrea siderea (continued)

\begin{tabular}{|c|c|c|c|c|c|c|c|c|c|}
\hline 1976 & 0.437 & 0.032 & 7 & 0.451 & 0.032 & 4 & 0.424 & 0.032 & 3 \\
\hline 1975 & 0.452 & 0.045 & 7 & 0.466 & 0.038 & 4 & 0.437 & 0.051 & 3 \\
\hline 1974 & 0.445 & 0.023 & 8 & 0.467 & 0.017 & 4 & 0.424 & 0.030 & 4 \\
\hline 1973 & 0.415 & 0.026 & 8 & 0.419 & 0.030 & 4 & 0.411 & 0.023 & 4 \\
\hline 1972 & 0.397 & 0.042 & 8 & 0.389 & 0.048 & 4 & 0.405 & 0.036 & 4 \\
\hline 1971 & 0.36 & 0.025 & 8 & 0.359 & 0.017 & 4 & 0.361 & 0.032 & 4 \\
\hline 1970 & 0.460 & 0.030 & 8 & 0.46 & 0.032 & 4 & 0.459 & 0.028 & 4 \\
\hline 1969 & 0.436 & 0.006 & 8 & 0.435 & 0.004 & 4 & 0.437 & 0.007 & 4 \\
\hline 1968 & 0.462 & 0.021 & 7 & 0.458 & 0.014 & 3 & 0.467 & 0.027 & 4 \\
\hline 1967 & 0.449 & 0.010 & 7 & 0.453 & 0.006 & 3 & 0.445 & 0.014 & 4 \\
\hline 1966 & 0.433 & 0.016 & 8 & 0.442 & 0.017 & 4 & 0.425 & 0.015 & 4 \\
\hline 1965 & 0.406 & 0.015 & 8 & 0.398 & 0.006 & 4 & 0.414 & 0.025 & 4 \\
\hline 1964 & 0.399 & 0.027 & 7 & 0.414 & 0.020 & 3 & 0.384 & 0.034 & 4 \\
\hline 1963 & 0.436 & 0.026 & 7 & 0.452 & 0.029 & 3 & 0.419 & 0.024 & 4 \\
\hline 1962 & 0.458 & 0.036 & 7 & 0.458 & 0.028 & 3 & 0.459 & 0.044 & 4 \\
\hline 1961 & 0.39 & 0.016 & 7 & 0.391 & 0.011 & 3 & 0.389 & 0.021 & 4 \\
\hline 1960 & 0.392 & 0.033 & 6 & 0.393 & 0.031 & 3 & 0.391 & 0.036 & 3 \\
\hline 1959 & 0.537 & 0.030 & 6 & 0.54 & 0.03 & 3 & 0.533 & 0.030 & 3 \\
\hline 1958 & 0.489 & 0.022 & 6 & 0.493 & 0.023 & 3 & 0.484 & 0.021 & 3 \\
\hline 1957 & 0.403 & 0.018 & 6 & 0.41 & 0.01 & 3 & 0.395 & 0.027 & 3 \\
\hline 1956 & 0.425 & 0.039 & 7 & 0.427 & 0.047 & 3 & 0.423 & 0.031 & 4 \\
\hline 1955 & 0.403 & 0.005 & 7 & 0.41 & 0 & 3 & 0.395 & 0.009 & 4 \\
\hline 1954 & 0.407 & 0.010 & 6 & 0.41 & 0.01 & 3 & 0.403 & 0.011 & 3 \\
\hline 1953 & 0.431 & 0.069 & 6 & 0.437 & 0.076 & 3 & 0.425 & 0.063 & 3 \\
\hline 1952 & 0.475 & 0.033 & 6 & 0.483 & 0.025 & 3 & 0.467 & 0.040 & 3 \\
\hline 1951 & 0.434 & 0.026 & 7 & 0.453 & 0.023 & 3 & 0.414 & 0.028 & 4 \\
\hline 1950 & 0.377 & 0.063 & 6 & 0.38 & 0.079 & 3 & 0.373 & 0.047 & 3 \\
\hline 1949 & 0.422 & 0.048 & 6 & 0.407 & 0.055 & 3 & 0.437 & 0.040 & 3 \\
\hline 1948 & 0.426 & 0.026 & 6 & 0.427 & 0.021 & 3 & 0.425 & 0.031 & 3 \\
\hline 1947 & 0.441 & 0.040 & 7 & 0.44 & 0.04 & 3 & 0.441 & 0.039 & 4 \\
\hline 1946 & 0.389 & 0.064 & 7 & 0.377 & 0.065 & 3 & 0.402 & 0.064 & 4 \\
\hline 1945 & 0.353 & 0.027 & 7 & 0.333 & 0.025 & 3 & 0.373 & 0.029 & 4 \\
\hline 1944 & 0.356 & 0.063 & 7 & 0.353 & 0.075 & 3 & 0.358 & 0.05 & 4 \\
\hline 1943 & 0.392 & 0.067 & 5 & & & & & & \\
\hline
\end{tabular}


DRTO Siderastrea siderea (continued)

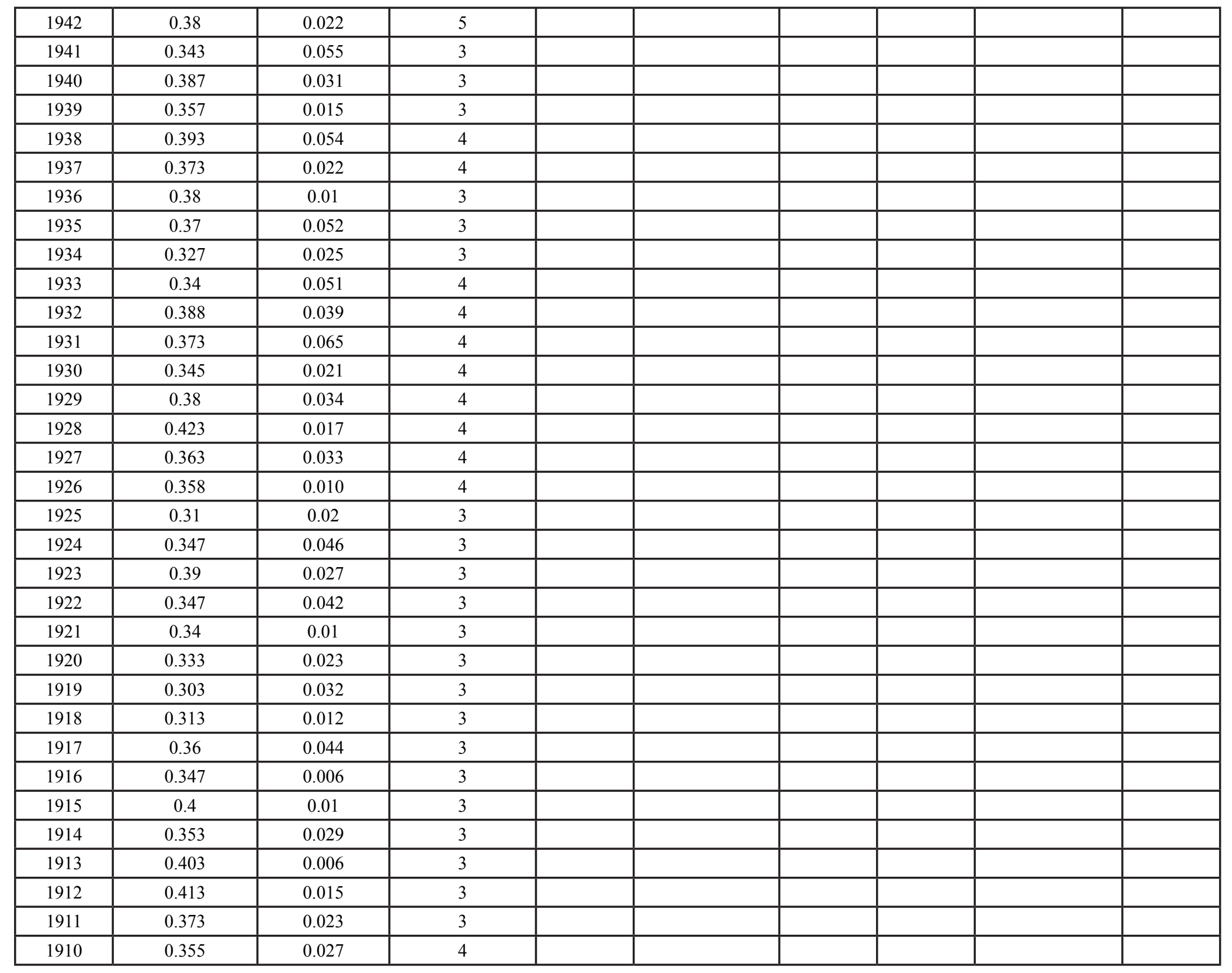


DRTO Siderastrea siderea (continued)

\begin{tabular}{|c|c|c|c|c|c|c|c|}
\hline 1909 & 0.323 & 0.070 & 3 & & & & \\
\hline 1908 & 0.327 & 0.025 & 3 & & & & \\
\hline 1907 & 0.34 & 0.017 & 3 & & & & \\
\hline 1906 & 0.297 & 0.031 & 3 & & & & \\
\hline 1905 & 0.417 & 0.095 & 3 & & & & \\
\hline 1904 & 0.46 & 0.036 & 3 & & & & \\
\hline 1903 & 0.437 & 0.025 & 3 & & & & \\
\hline 1902 & 0.44 & 0.053 & 3 & & & & \\
\hline 1901 & 0.377 & 0.015 & 3 & & & & \\
\hline 1900 & 0.413 & 0.015 & 3 & & & & \\
\hline 1899 & 0.397 & 0.021 & 3 & & & & \\
\hline 1898 & 0.457 & 0.012 & 3 & & & & \\
\hline 1897 & 0.363 & 0.015 & 3 & & & & \\
\hline 1896 & 0.347 & 0.015 & 3 & & & & \\
\hline 1895 & 0.393 & 0.059 & 3 & & & & \\
\hline 1894 & 0.403 & 0.012 & 3 & & & & \\
\hline 1893 & 0.323 & 0.021 & 3 & & & & \\
\hline 1892 & 0.403 & 0.110 & 3 & & & & \\
\hline 1891 & 0.433 & 0.083 & 3 & & & & \\
\hline 1890 & 0.39 & 0.046 & 3 & & & & \\
\hline 1889 & 0.383 & 0.074 & 3 & & & & \\
\hline Averagee & 0.41 & 0.03 & & 0.45 & 0.03 & 0.45 & 0.03 \\
\hline
\end{tabular}




\section{DRTO Diploria strigosa}

\begin{tabular}{|c|c|c|c|c|c|c|}
\hline Year & C1 & C1 Error (1б) & C1 n & MK & MK Error (1б) & MK n \\
\hline 2007 & 0.713 & 0.040 & 3 & 0.552 & 0.090 & 3 \\
\hline 2006 & 0.832 & 0.063 & 4 & 0.556 & 0.023 & 3 \\
\hline 2005 & 0.724 & 0.040 & 5 & 0.598 & 0.105 & 3 \\
\hline 2004 & 0.666 & 0.064 & 5 & 0.556 & 0.030 & 3 \\
\hline 2003 & 0.701 & 0.056 & 6 & 0.604 & 0.058 & 3 \\
\hline 2002 & 0.743 & 0.086 & 6 & 0.574 & 0.037 & 3 \\
\hline 2001 & 0.683 & 0.026 & 6 & 0.604 & 0.045 & 4 \\
\hline 2000 & 0.777 & 0.089 & 6 & 0.567 & 0.039 & 5 \\
\hline 1999 & 0.788 & 0.091 & 6 & 0.561 & 0.017 & 5 \\
\hline 1998 & 0.685 & 0.063 & 6 & 0.548 & 0.040 & 5 \\
\hline 1997 & 0.637 & 0.047 & 6 & 0.583 & 0.041 & 5 \\
\hline 1996 & 0.753 & 0.036 & 6 & 0.657 & 0.086 & 5 \\
\hline 1995 & 0.763 & 0.021 & 6 & 0.674 & 0.111 & 5 \\
\hline 1994 & 0.758 & 0.104 & 6 & 0.659 & 0.083 & 4 \\
\hline 1993 & 0.675 & 0.060 & 5 & 0.641 & 0.099 & 5 \\
\hline 1992 & 0.663 & 0.020 & 5 & 0.582 & 0.071 & 5 \\
\hline 1991 & 0.748 & 0.034 & 5 & 0.59 & 0.121 & 3 \\
\hline 1990 & 0.792 & 0.042 & 5 & 0.604 & 0.102 & 3 \\
\hline 1989 & 0.835 & 0.014 & 5 & 0.595 & 0.067 & 4 \\
\hline 1988 & 0.742 & 0.088 & 5 & 0.582 & 0.037 & 3 \\
\hline 1987 & 0.786 & 0.043 & 4 & 0.512 & 0.059 & 3 \\
\hline 1986 & 0.726 & 0.064 & 4 & 0.564 & 0.057 & 3 \\
\hline 1985 & 0.711 & 0.081 & 4 & 0.488 & 0.058 & 3 \\
\hline 1984 & 0.729 & 0.039 & 4 & 0.561 & 0.017 & 3 \\
\hline 1983 & 0.721 & 0.046 & 4 & 0.554 & 0.037 & 3 \\
\hline 1982 & 0.772 & 0.033 & 4 & 0.513 & 0.027 & 3 \\
\hline 1981 & 0.742 & 0.025 & 4 & 0.531 & 0.043 & 3 \\
\hline 1980 & 0.83 & 0.02 & 3 & 0.607 & 0.092 & 3 \\
\hline 1979 & 0.818 & 0.003 & 3 & 0.686 & 0.115 & 3 \\
\hline 1978 & 0.645 & 0.012 & 4 & 0.747 & 0.027 & 3 \\
\hline 1977 & 0.766 & 0.021 & 4 & 0.633 & 0.062 & 4 \\
\hline 1976 & 0.688 & 0.026 & 3 & 0.614 & 0.042 & 4 \\
\hline
\end{tabular}


DRTO Diploria strigosa (continued)

\begin{tabular}{|l|l|l|l|l|l|l|}
\hline 1975 & 0.725 & 0.074 & 3 & 0.594 & 0.084 & 4 \\
\hline 1974 & 0.783 & 0.037 & 3 & 0.526 & 0.051 & 3 \\
\hline 1973 & 0.757 & 0.040 & 3 & 0.552 & 0.051 & 3 \\
\hline 1972 & 0.733 & 0.025 & 3 & & & \\
\hline 1971 & 0.76 & 0.040 & 3 & & & \\
\hline 1970 & 0.733 & 0.051 & 3 & & & \\
\hline 1969 & 0.735 & 0.013 & 3 & & & \\
\hline 1968 & 0.626 & 0.021 & 4 & & & \\
\hline 1967 & 0.857 & 0.020 & 4 & & & \\
\hline 1966 & 0.854 & 0.006 & 3 & & & \\
\hline 1965 & 0.704 & 0.022 & 3 & & & \\
\hline 1964 & 0.666 & 0.033 & 3 & & & \\
\hline 1963 & 0.706 & 0.009 & 3 & & & \\
\hline 1962 & 0.665 & 0.024 & 4 & & & \\
\hline 1961 & 0.683 & 0.026 & 5 & & & \\
\hline 1960 & 0.818 & 0.026 & 4 & & & \\
\hline 1959 & 0.765 & 0.013 & 4 & & & \\
\hline 1958 & 0.648 & 0.039 & 4 & & & \\
\hline 1957 & 0.71 & 0.035 & 3 & & & \\
\hline 1956 & 0.637 & 0.025 & 3 & & & \\
\hline 1955 & 0.617 & 0.006 & 3 & & & \\
\hline 1954 & 0.697 & 0.035 & 3 & & & \\
\hline & & & & & & \\
\hline Average & 0.73 & 0.04 & & & & \\
\hline
\end{tabular}

